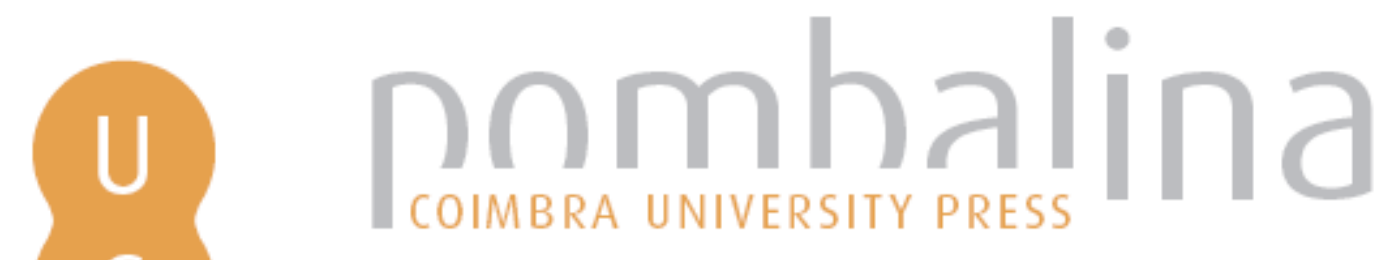

\title{
A comunhão do logos
}

\author{
Autor(es): $\quad$ Lopes, Rodolfo
}

Publicado por: Imprensa da Universidade de Coimbra

URL

persistente: URI:http://hdl.handle.net/10316.2/31608

DOI: $\quad$ DOI:http://dx.doi.org/10.14195/978-989-8281-45-6_2

Accessed : $\quad$ 26-Apr-2023 11:53:30

A navegação consulta e descarregamento dos títulos inseridos nas Bibliotecas Digitais UC Digitalis, UC Pombalina e UC Impactum, pressupõem a aceitação plena e sem reservas dos Termos e Condições de Uso destas Bibliotecas Digitais, disponíveis em https://digitalis.uc.pt/pt-pt/termos.

Conforme exposto nos referidos Termos e Condições de Uso, o descarregamento de títulos de acesso restrito requer uma licença válida de autorização devendo o utilizador aceder ao(s) documento(s) a partir de um endereço de IP da instituição detentora da supramencionada licença.

Ao utilizador é apenas permitido o descarregamento para uso pessoal, pelo que o emprego do(s) título(s) descarregado(s) para outro fim, designadamente comercial, carece de autorização do respetivo autor ou editor da obra.

Na medida em que todas as obras da UC Digitalis se encontram protegidas pelo Código do Direito de Autor e Direitos Conexos e demais legislação aplicável, toda a cópia, parcial ou total, deste documento, nos casos em que é legalmente admitida, deverá conter ou fazer-se acompanhar por este aviso. 
Colecção Autores Gregos e Latinos

SÉRIE ENSAIOS

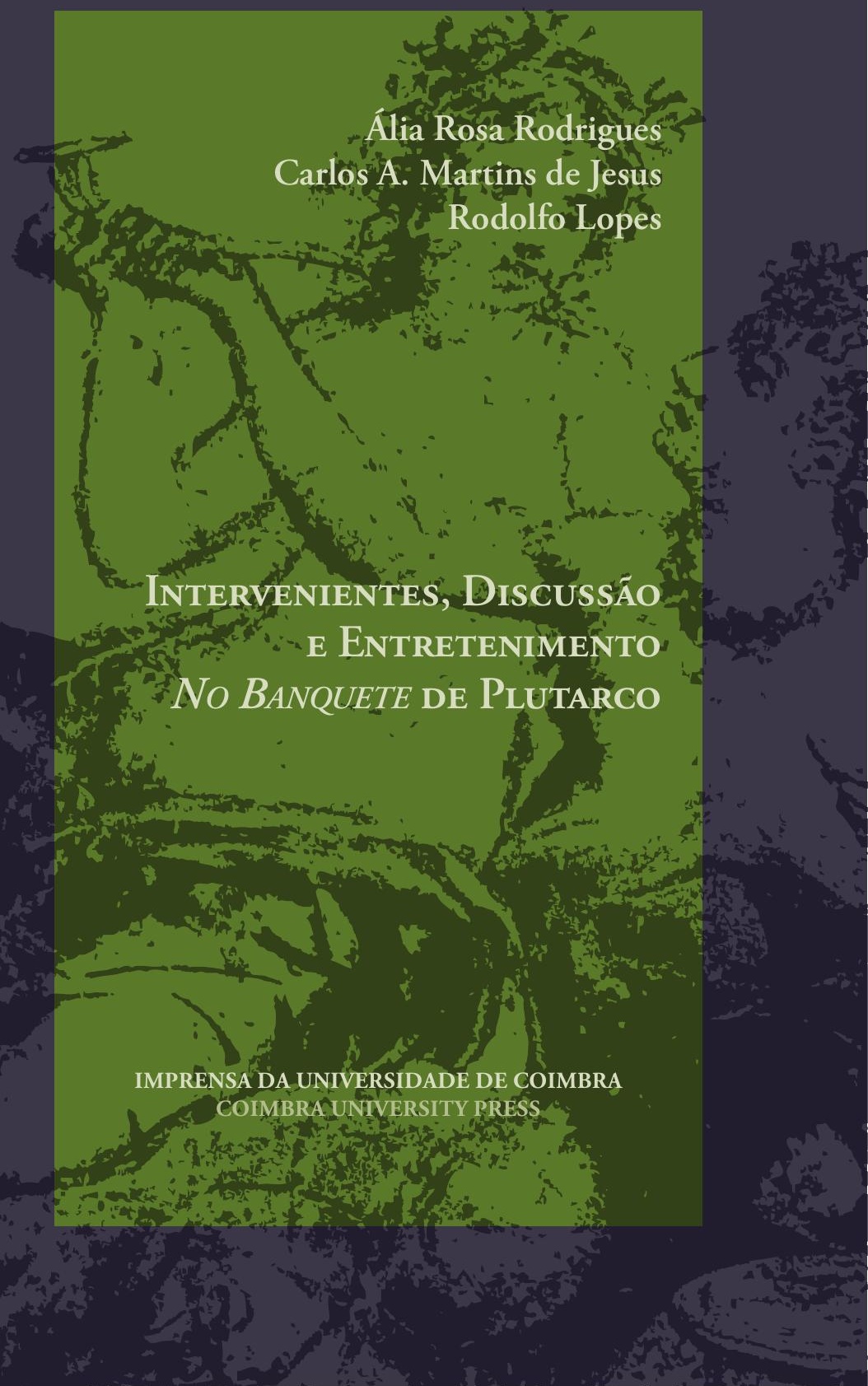




\section{Parte II}

A COMUNHÃo DO LOGOS

Rodolfo Lopes 
O convívio em torno de uma mesa é uma prática que segue o Homem desde os seus primeiros passos enquanto animal social; é, por isso, detectável e até evidente logo nos primórdios do registo textual. Mais do que simples referências ou alusóes, os autores-fundadores do pensamento ocidental dedicaram ao contexto do banquete um vasto número de considerações, permitindo assim reconstituir algumas das normas que presidiam a este tipo de reunióes ${ }^{1}$.

No que à conversação diz respeito, os indícios são bastante claros quanto ao seu papel na estrutura do banquete: nalguns casos náo mais do que motor de interacção entre os participantes; noutros não menos que motivo e finalidade do próprio encontro convival.

A concepção de banquete como espaço de conversação surge desde logo em Homero. Todavia distantes da codificação mais elaborada de épocas posteriores - por exemplo, a divisão entre $\delta \varepsilon \tilde{\pi} \pi v o v$ e

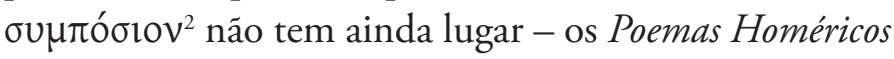

${ }^{1}$ Para uma visāo sintética da história do banquete, vide Murray 1990 3-13.

${ }^{2} \mathrm{Um}$ banquete grego era dividido em duas partes distintas: na primeira - o $\delta \varepsilon \tilde{\pi} \pi v o v$ - era servida a comida, enquanto que

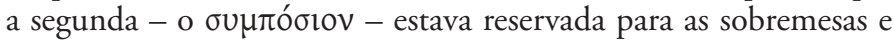


dáo já conta da importância da vertente discursiva. Um exemplo é a chamada "embaixada a Aquiles" no Canto IX da Ilíada, durante a qual o anfitriáo recebe Ájax, Ulisses e Fénix que o tentam convencer a voltar ao combate; todo o processo de argumentação (e respectivo contraditório) é acompanhado pelo consumo partilhado de vinho. Outro exemplo será o Canto VII da Odisseia, quando Ulisses narra as incidências da viagem ao rei Alcínoo, que o recebe justamente com um banquete ${ }^{3}$. Neste como noutros casos análogos, a conversação está focada nas intençôes e motivaçôes do interveniente que chega ao local, razão pela qual se relaciona estreitamente com os rituais de hospitalidade vigentes.

Durante a Época Arcaica, esta prática tornou-se bastante recorrente, como sugere a diversidade de testemunhos que os poetas deixaram a este respeito. Além disso, este tipo de convívios e a noção de comensalidade assumiram uma orientação diversa, na medida em que as atenções deixaram de estar viradas para o interveniente que vinha de fora, para se privilegiar uma interacção mais marcada entre todos os convivas igualmente estruturada pelo uso da palavra. Em traços gerais, os banquetes desta época, por um lado, desenvolviam-se num ambiente festivo e configuravam-se como espaço de divertimento, em que dominavam a poesia, a música

para o vinho que, misturado com água, era bebido em conjunto

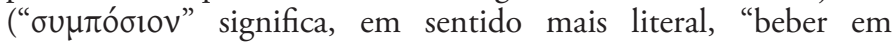
conjunto"). Sobre esta divisão, vide Murray 1990 6. Note-se, além disso, que, em Homero, o termo para "banquete" não é ouนtó

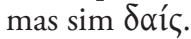

${ }^{3}$ Cf. infra p. 110. 
ou a dança; por outro, afirmavam-se como ponto de intersecção entre passado e presente por combinarem narrativas etnográficas reminiscentes de tempos heróicos com elogios e censuras a temas actuais, ou mesmo a personagens presentes no local ${ }^{4}$.

Ainda num contexto de divertimento, mas já na Época Clássica, merece também ser referido, a título exemplificativo, o banquete descrito por Aristófanes nas Vespas (vv. 1175 sqq.). O paradigma continua a ser o do cultivo da palavra, mas completamente invertido pelo contexto cómico: a conversação dá lugar ao desentendimento e o encontro degenera em insultos mútuos e violência entre os participantes já perdidamente embriagados.

Neste período, o convívio em torno da mesa e do vinho começa a assumir outros contornos; ou melhor, a admitir outro tipo de orientaçáo. Trata-se do banquete enquanto espaço de discussão filosófica, tal como foi configurado principalmente no Banquete de Platão. Poder-se-ia acrescentar também o contributo da obra homónima de Xenofonte, mas essa é uma questão algo delicada, dadas as implicaçóes da frase que surge na sua abertura:

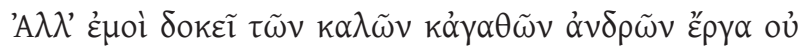

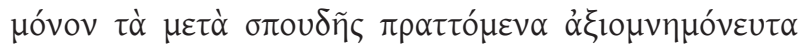

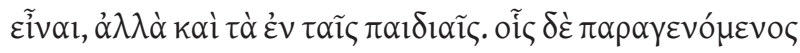

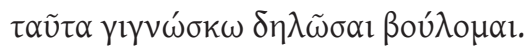

${ }^{4}$ Sobre os banquetes até à Época Clássica, vide Rösler 1990 231-232; Bowie 1993 355-366. 
Pois, a mim, não me parece que sejam menos dignas de lembrança as acçóes sérias dos homens de bem do que os seus momentos de irreflexão. E porque eu próprio os presenciei, quero agora transmitir o que sei ${ }^{5}$.

Ora, como é sabido, não são estas as intençōes de Platão quando escreve o seu Banquete; pelo contrário, já que o assunto é puramente filosófico - avesso, pois, à “irreflexão".

É notório que desde Homero o contexto convival privilegiava a palavra; em certo sentido, pode dizer-se que o logos era um elemento decisivo do funcionamento do banquete. Contudo, o significado que assume é tão-só o de "conversação" e não ainda o de "diálogo" - tomando esta palavra no seu sentido mais literal. A grande alteração no logos será, então, a passagem de "conversar" para "discutir"; ou melhor, para "discutir dialecticamente".

Não é claro o modo como a transição se processou; ou seja, não é possível saber exactamente quando e em que circunstâncias surgiu o diálogo filosófico, porque não há dados suficientes que sustentem uma tese minimamente plausível $^{6}$. As propostas dos autores antigos são bastante divergentes: de acordo com um fragmento atribuído a Aristóteles (fr. 72 Rose $^{3}=$ D.L. 3.48; Ath. 11.112), o primeiro autor de uma obra deste tipo foi Alexâmeno de Teos (um discípulo de Sócrates); Diógenes Laércio (3.48),

${ }^{5}$ X. Smp. 1.1. A tradução é de Pinheiro 2008 31; a mesma autora (24-25) faz questão de sublinhar o carácter "burlesco" do Banquete de Xenofonte, por oposição ao de Platão que classifica de "sério".

${ }^{6}$ As hipóteses são várias, mas todas elas carecem de consistência. Para uma discussão deste problema, vide Vetta 2000 219-22. 
por seu turno, acrescenta que também Favorino pensava como Aristóteles, mas, na sua opinião, os fundadores deste género terão sido Zenão e Protágoras.

Dadas tais e tantas incertezas, a atitude mais segura será atribuir a Platão a iniciativa de compor diálogos filosóficos e, mais propriamente, dramatizaçóes mais sérias do ambiente convival ${ }^{7}$. Note-se, porém, que o estabelecimento do banquete filosófico não está confinado às linhas do Banquete, já que o assunto é igualmente abordado noutros diálogos. Por exemplo, no Protágoras (347c-d), Sócrates faz questão de distinguir dois tipos de banquete: por um lado, o dos homens

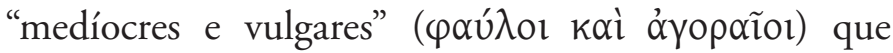
necessitam do som das flautas para preencher o vazio deixado pela incapacidade de produzir discursos; e, por outro lado, o dos homens "perfeitos" ( $\kappa \alpha \lambda$ oi kả $\gamma \alpha \theta o i ́)^{8}$ que dispensam a presença de quaisquer entretenimentos, porque a discussão ordenada faz com que se bastem a si próprios, mesmo que consumam vinho em demasia ${ }^{9}$. Livre de animaçóes fúteis e infrutíferas, o banquete tornar-se-á num "festim de discursos" ${ }^{10}$ (logoi); ou seja, num encontro filosófico.

${ }^{7}$ Sobre a "dramatização", em sentido mais literal, vide infra pp. 91-109.

${ }^{8}$ A $\kappa \alpha \lambda$ к $\alpha \gamma \alpha \theta i ́ \alpha$ correspondia a um estado ideal de excelência educativa que combinava duas dimensões de excelência: a física ( $\tau$ ò

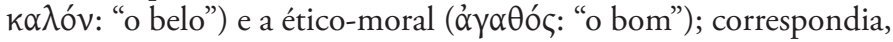
numa palavra, à "perfeição".

${ }^{9}$ Note-se que no Banquete de Platão a flautista é dispensada, já que as discussões entre os participantes são suficientes (176e).

${ }^{10}$ A associação do banquete filosófico a um "festim de discursos" é bastante recorrente nos diálogos platónicos (e.g. Grg. 447a; $R$. 352b, 354a; Ti. 20c). 


\section{A filosofia nas $Q C$}

Dito isto, será necessário, em primeiro lugar, perceber em que condiçóes o logos do texto de Plutarco se compatibiliza com o de Platáo e, consequentemente, se afasta do de Aristófanes. Em suma, trata-se de saber como as $Q C$ se inscrevem (ou podem inscrever-se) na linha do banquete filosófico. Os indícios são vários.

Primeiro, a intenção do autor: Plutarco, enquanto narrador, vincula explicitamente a sua obra àquela tradição. Logo no proémio ao Livro I (612E), secção em que justifica o propósito do texto, cita o nome de alguns filósofos, com Platão à cabeça ${ }^{11}$, que registaram as discussóes mantidas durante o banquete; como que assumindo a continuidade das autoridades que o precederam na matéria.

Por outro lado, a tarefa de conservar a memória do que foi dito traz associada a necessidade inversa de manter no esquecimento alguns excessos cometidos; uma forma de memória selectiva será, pois, o instrumento perfeito para consolidar os pontos de contacto com a tradição filosófica e, ao mesmo tempo, soterrar o que dela se afaste. Em sentido análogo, no proémio ao Livro VI, Plutarco insiste na necessidade de registar tudo quanto fora dito durante o convívio simpótico, deixando de lado os aspectos materiais (as iguarias e

11 São também referidos Xenofonte, Aristóteles, Espeusipo, Epicuro, Prítanis, Jerónimo e Díon. É curioso notar que nenhum dos autores citados é anterior a Platáo. Sobre os problemas que esta lista levanta, vide Teodorsson ad loc.; Vetta 2000222. 
o vinho consumido, por exemplo), tal como Platáo e Xenofonte tinham feito (686D).

Segundo, as exigências éticas: a toda a discussão deve presidir um conjunto de prescriçóes que a mantenham ordenada. Quer isto dizer que, de modo a evitar que os banquetes caiam no desgoverno próprio dos homens "medíocres e vulgares" de que falava Sócrates no Protágoras, e, em vez disso, seguir na linha dos homens "perfeitos", é necessário regular a conversação de acordo com critérios éticos específicos e rigorosos ${ }^{12}$. Como bem observa Van der Stockt (2000 94), as QC reúnem um grupo de homens cultos e moderados que seguem um modelo de conversação e convívio assente nos conceitos

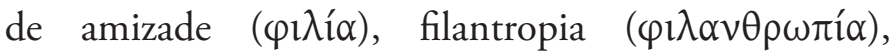

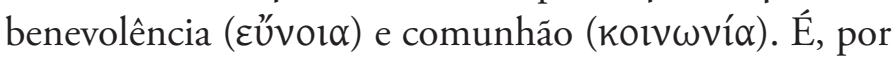
isso, muito raro encontrar ao longo do texto violaçóes a estes critérios $^{13}$, posto que não são simples marcos de argumentação; antes se afiguram como elementos vitais a cultivar pelos participantes.

Terceiro, a filosofia é tema de discussão: entre os vários assuntos abordados ao longo dos nove livros, contam-se alguns que podemos considerar filosóficos. Como veremos, será uma versão adequada ao contexto do banquete, mais propriamente à inevitável disparidade intelectual dos participantes ${ }^{14}$; porém,

${ }^{12}$ Sobre alguns dos principais traços éticos latentes nas $Q C$, vide Ribeiro Ferreira 2008 16-20.

13 Vide alguns exemplos em Martín García 1987 11-12; Van der Stock 2000 93-94.

14 Não obstante ligeiras divergências sócio-culturais, os participantes são, em geral, homens cultos e educados. Plutarco chega a referir-se a alguns como filósofos (cf. Klotz 2007 659-sqq.). 
o logos em causa nas discussôes está bastante mais próximo da tradição fundada por Platão do que da simples conversa de ocasiáo própria doutros ambientes. Esta intenção é particularmente notória, quando Plutarco adianta que, ao invés de entretenimentos, os participantes devem buscar a diversão "através

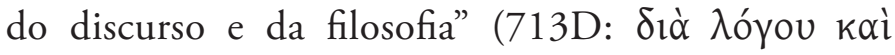
$\left.\varphi \imath \lambda \circ \sigma \circ \varphi^{\prime} \alpha \varsigma\right)^{15}$. Note-se o pormenor de congregar ambas as noçóes unidas no mesmo sintagma, como que sublinhando a sua complementaridade; mais ainda, a sua concomitância, posto que também associa a estes dois elementos um terceiro de particular importância: $\pi \rho o ́ \beta \lambda \eta \mu \alpha$. É justamente este o termo que designa as várias subdivisóes (as "questôes") dos nove livros da obra, e que chega a ser equacionado com o próprio discurso filosófico: por exemplo, no já citado proémio ao Livro VI, Plutarco reincide na necessidade de guardar memória das conversas tidas à mesa, dado que se trata de "problemas e discursos

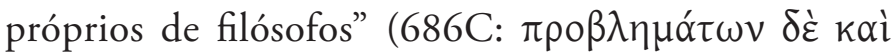

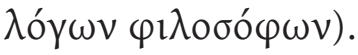

Não é de todo acidental que o primeiro desses $\pi \rho \circ \beta \lambda \eta ́ \mu \alpha \tau \alpha$ do livro inaugural seja sobre a aceitabilidade da filosofia no contexto simpótico: "Se se deve filosofar durante a bebida". A posição capital desta questão e o seu conteúdo estabelecem as linhas programáticas de acordo com as quais as discussóes desta natureza se orientaráo; ou seja, definem em que termos e sob que

Sobre os participantes em geral, vide supra pp. 15-32.

${ }^{15}$ Os entretenimentos podem ser admitidos desde que tragam algum benefício à conversação (711A). 
condiçóes a filosofia pode ou deve ser tema a debater. As directrizes são claras: ao contrário dos Persas, que costumavam manter a filosofia afastada do banquete e, em vez disso, preferiam actividades mais lúdicas (613A), os banquetes de Plutarco aceitá-la-ão de bom grado, mas numa versáo personalizada. Muito sucintamente, dado que voltarei ao assunto numa secção posterior, o veredicto desta primeira questão determina dois tipos de restriçóes: um relacionado com o método discursivo, outro com o conteúdo.

$\mathrm{O}$ caminho pelo qual se procura atingir a conclusão de um determinado problema não pode ser acidentado; o discurso (logos) deve, pois, ser guiado mais

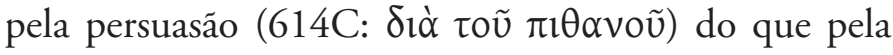

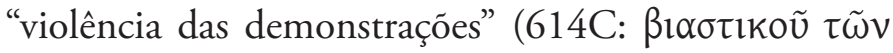
$\alpha \dot{\pi} 0 \delta \varepsilon \dot{\xi} \xi \varepsilon \omega v)$. Em termos aristotélicos, se quisermos, o debate deverá desenrolar-se pela maleabilidade da palavra retórica em vez de se complicar na frieza do raciocínio apodíctico.

Quanto aos conteúdos, as questóes a tratar

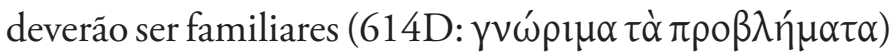

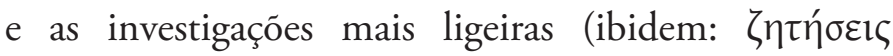

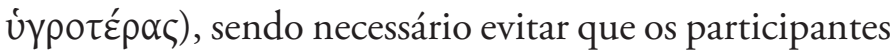
se detenham em assuntos "melindrosos e insondáveis"

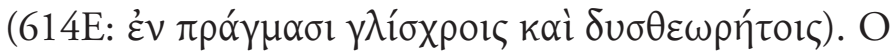
paradigma é o próprio Platão, que, segundo Plutarco, defende no Banquete - justamente - uma orientação similar $^{16}(614 \mathrm{C}-\mathrm{D})$ :

16 Sobre o nível retórico usado por Plutarco nas $Q C$, vide Matino 1991 295-6, 313 e Gonzàlez Julià 2009 67-71. 


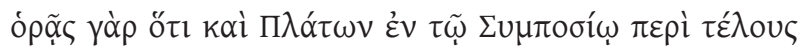

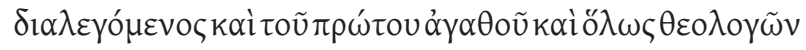

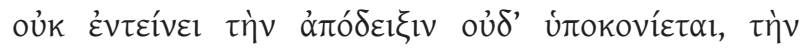

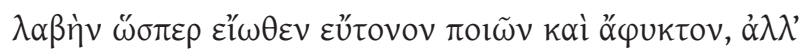

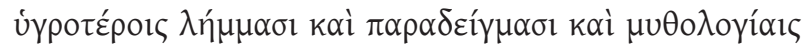

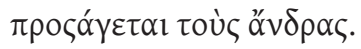

Na verdade, sabes que até Platão, quando no Banquete fala sobre o fim último e o primeiro bem e aborda a divindade em geral, náo se alonga na demonstração nem se enche de pó, de modo a que, como era costume, conseguisse uma pega firme e sem fuga; pelo contrário, atraía os homens com laços mais fluidos, com exemplos e mitos.

Mesmo os aspectos mais complexos da filosofia ("o primeiro bem" e a "divindade") são (ou podem ser) dados a conhecer mais facilmente através de um discurso acessível a todos os homens do que pelos instrumentos implacáveis da analítica. Por meio da palavra poética (dada por "exemplos e mitos"), cujo poder é quase encantatório (já que "atrai"), a aproximação aos homens será bastante mais eficaz do que recorrendo às estratégias ofensivas próprias de um confronto, como o pó usado no pugilato para ganhar mais aderência; é que não se trata de agarrar bruscamente os ouvintes, mas sim de os enlaçar suavemente.

No fundo, esta concepção particular da filosofia aspira, acima de tudo, a que todos os participantes sem excepção possam intervir e comungar da prática argumentativa ordenada e frutífera - dois tópicos centrais que, como veremos, perpassam ao longo de todo o debate - filosófico ou não. 


\section{O vinho como elemento catalisador}

A diversidade intelectual dos participantes, aliada à preocupação de tornar o debate universal, traz um problema à concepção do banquete segundo Plutarco: como manter elevado o nível filosófico das discussóes e, ao mesmo tempo, torná-lo acessível aos menos conhecedores deste tipo de saber? Trata-se, pois, de assemelhá-lo ao convívio daquele tipo de homens a que Sócrates chamara "perfeitos", mas com o problema de necessariamente incluir alguns "medíocres e vulgares", como os havia entre os participantes das $Q C$. À primeira vista, as hipóteses serão duas: ou apostar numa versão simplificada da filosofia, ou potenciar as capacidades dos "não-especialistas". Na verdade, Plutarco tenta combinar um pouco de ambas.

Aludi já à primeira e, posteriormente, tratarei de a analisar em detalhe. Quanto à segunda, ela consiste num aproveitamento do vinho, um elemento central do convívio, como catalisador das capacidades discursivas.

A este respeito, convém ter presente uma ideia que Plutarco concebe no Banquete dos Sete Sábios - um texto igualmente simpótico, mas com diferenças abismais no que toca à natureza dos participantes. A dada altura, Mnesífilo refere que o carácter dos homens que Periandro (o anfitriáo) reunira àquela mesa dispensava a presença do vinho, posto que as suas capacidades naturais eram suficientes para gerar conversação - o prazer mais elevado de um banquete - a qual ficava à disposição dos convivas como um krater $^{17}$ de que todos pudessem

${ }^{17} \mathrm{O}$ krater era uma peça cerâmica colocada ao centro da mesa 
partilhar (156D). Mas, como sabemos, esta ideia não se poderia aplicar às $Q C$, dada a diversidade cultural $\mathrm{e}$ intelectual dos participantes. Como, então, superar este tipo de constrangimento? A estratégia adoptada por Plutarco é deveras engenhosa.

A passagem do Banquete dos Sete Sábios a que me refiro não sugere que o vinho deva ser banido dos banquetes, mas tão-só que ele é desnecessário quando todos os convivas já reúnem por natureza as condiçóes para gerar e manter um debate frutífero e ordenado. Então, o inverso será provavelmente válido: se os convivas não reunirem essas condiçôes, talvez a introdução do vinho ajude de algum modo a obtê-las. É justamente esta a ideia presente nas $Q C$. Mantendo a metáfora do krater enquanto princípio de comunhão, Plutarco inverte os termos e coloca dentro dele o vinho cujo consumo há-de proporcionar conversação igualmente comum; como se à mistura da água com o vinho dentro do krater se juntasse o logos, originando concomitantemente o efeito desejado: o debate ordenado.

Importa sublinhar que neste contexto o termo logos terá dois sentidos diversos mas absolutamente complementares. Por um lado, representa a racionalidade que disciplina o consumo de vinho - a "justa medida", se quisermos. Por outro, diz respeito ao discurso argumentativo - um correlato linguístico daquela racionalidade alimentado por esse consumo.

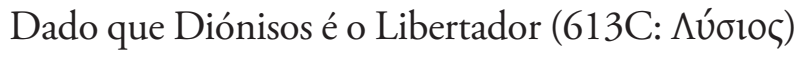
pelo facto de "soltar os freios da língua" (613C: $\tau \tilde{\eta} \varsigma$

para fazer a mistura do vinho, da qual os convivas se serviam. 


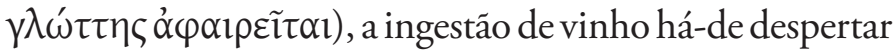
em cada participante uma predisposição para o cultivo da palavra. Todavia, o consumo deverá ser moderado, sob pena de o convívio resvalar numa contrafacção do banquete próxima daquele tipo de encontros próprios dos homens "medíocres e vulgares"; ou mesmo semelhante ao que Aristófanes descreve nas Vespas.

Recorrendo à fisiologia platónica, Plutarco explica como este fenómeno se processa. Quando o vinho circula pelo corpo juntamente com o logos enquanto racionalidade, seguirá até à alma e, automaticamente, estimulará a parte intelectiva (o nous) a produzir o segundo tipo de logos - o discurso racional. Deste modo, gera-se a filantropia (um dos principais critérios éticos) e são fortalecidos os laços de amizade entre os convivas (660B) - que é afinal o propósito de qualquer banquete. Se, em vez disso, o vinho circular errante (660C: $\pi \lambda \alpha v \omega ́ \mu \varepsilon v o \varsigma)$ pelo corpo sem a mediação do logos, não produzirá nada senão saciedade (660C: $\pi \lambda \eta \sigma \mu o v \tilde{\eta} \varsigma)$ - isto é, uma mera manifestação sensorial produzida somente na dimensão corporal, sem quaisquer pretensôes de modelação de carácter.

Em suma, o vinho deverá ser regulado e dirigido pelo logos enquanto racionalidade, para que, inversamente, gere logos enquanto discurso racional. A interdependência dos dois elementos, de cujo equilíbrio depende a harmonia entre os convivas, será a chave do debate organizado em comunhão; como se estivessem misturados num krater à disposiçáo de todos ${ }^{18}$.

18 Esta conexão entre vinho e logos é pormenorizadamente 


\section{Uma versão personalizada da filosofia}

Como já foi dito, a diversidade sócio-cultural entre os participantes é uma condição inalienável dos convívios registados nas $Q C$; razão pela qual traz dificuldades à sua aproximação do banquete filosófico. Contudo, Plutarco aproveita esta característica para resolver o problema que ela própria levanta, na medida em que a converte em princípio de uniformização por mais paradoxal que esta ideia possa parecer. $\mathrm{O}$ objectivo é criar uma unidade por meio da diferença, isto é, congregar as várias divergências num todo harmonioso e uno; tal como numa sinfonia, onde a convivência de vários instrumentos com sonoridades diversas (cordas, metais etc.) pode, sob uma direcção competente, produzir uma sonoridade conjunta bastante harmoniosa - neste caso, a batuta seria agitada pela combinação de logos e vinho. A imagem de Plutarco é semelhante (613E):

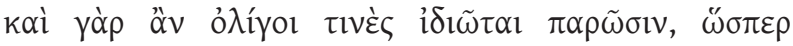

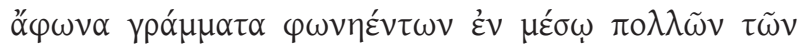

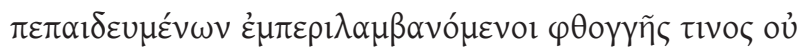

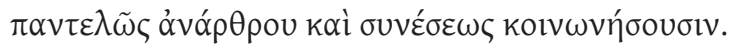

Ese estiverem presentes alguns ignorantes no meio de muitos instruídos, envolvidos que estâo como consoantes entre vogais, compartilharão um som não de todo desarticulado e confluente.

analisada em Romeri 2002 172-177. 
O contexto é justamente a aceitabilidade da filosofia no banquete; mais propriamente, o modo como se podem articular, num mesmo espaço, os conhecedores e os ignorantes. A convivência será, pois, como a linguagem humana: ainda que composta por sons divergentes (consoantes mudas e vogais, por definição, sonoras), é harmoniosa. O exemplo não é casual; recorrer à linguagem verbal sugere, por um lado, a naturalidade desta adaptação, e, por outro, uma certa marca de racionalidade. É que o efeito harmónico da linguagem humana náo depende de qualquer artifício ou esforço, pois produz-se naturalmente; mais, a linguagem é justamente o instrumento que dá corpo à sua outra especificidade, talvez a mais determinante: a faculdade racional e intelectiva.

De modo a que no banquete se possam sintonizar as ditas diferenças entre os participantes, é necessário, em primeiro lugar, preparar um ambiente favorável; ou seja, um contexto amistoso e tolerante que, em vez de acentuar as diferenças, as possa dissipar ou mesmo eliminar de todo. As questóes não devem, pois, centrar-se em problemas excessivamente complexos para não excluir os "não-especialistas", como já referi, e também de modo a impedir que o convívio degenere

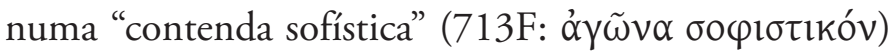
ou própria da "ágora e da assembleia" (713F4-5:

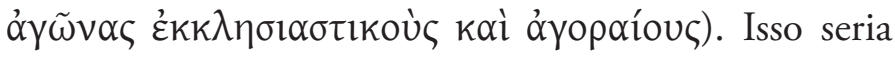
a contrafacção do modelo de discussão ordenada, própria daqueles que náo sabem ou não querem seguir os preceitos éticos que regulam uma argumentação 
saudável. Além dos Sofistas (famosos desde sempre pelo uso anético da palavra), são visados os que debatem desregradamente no espaço público, aqueles a que Sócrates chamara "vulgares"19.

Tal como aconselhava Demócrito (614E),

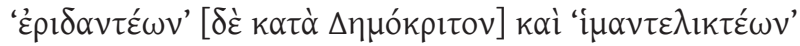

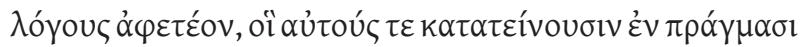

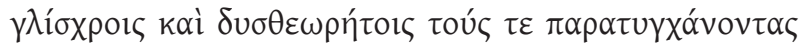
$\dot{\alpha} v i \tilde{\omega} \sigma l v$.

Devemos evitar conversas próprias de 'litigantes' e 'prestidigitadores', que, ao estenderem-se por questôes melindrosas e obscuras, enfastiam a assistência.

Pelo contrário, como também já ficou dito, as investigaçóes devem ser ligeiras e acessíveis, para que todos possam de algum modo tomar parte do logos entendido simultaneamente enquanto racionalidade e discurso racional. Evidentemente que o cultivo de enigmas seria não só inútil, como também constrangedor: aqueles que os conseguissem resolver estariam para os incapazes como "prestidigitadores" para um público boquiaberto.

Quanto à formulação das questóes, deve ser também acessível a todos os participantes. Trata-se de tornar apetecível e atraente a palavra filosófica, um pouco à imagem de Platão, como já referi anteriormente a propósito do uso de mitos, de exemplos e de um tipo

${ }^{19}$ Note-se que o termo usado por Plutarco é precisamente o mesmo a que Platão recorrera: $\alpha$ yyopaĩot. 
de discurso mais próximo da retórica e da poética do que da lógica.

Mas, ao propor uma versão aligeirada da filosofia para o contexto simpótico, Plutarco parece fazê-la descer a um nível demasiadamente inferior para um banquete de filósofos; ou seja, como torná-la acessível aos mais incultos e, ao mesmo tempo, conservar os elementos suficientes para que o banquete admita o título "filosófico"? Se a lógica, que tradicionalmente tinha o estatuto de simples propedêutica ${ }^{20}$, é considerada uma tortuosidade a evitar, o que dizer, por exemplo, da metafísica?

A estratégia é, mais uma vez, engenhosa. Plutarco faz descer a filosofia das especulações teoréticas até ao mundo dos homens e, aproveitando um motivo de matriz marcadamente estóica, declara-a uma "arte

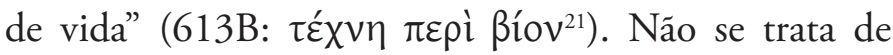
reduzir toda a filosofia à ética, mas sim de reconduzir os aspectos teóricos aos seus correlatos práticos, afastando-a do paradigma aristotélico de "ciência da

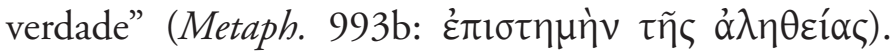
No fundo, é uma concepção muito próxima da do "arquétipo" Sócrates, segundo o qual a filosofia estava

${ }^{20}$ Para o próprio Plutarco seria também um assunto acessório, posto que nem sequer é possível perceber que sistema seguia (se o aristotélico, se o estóico), dado o táo reduzido número de consideraçôes que dedica a este aspecto; sobre o problema, vide Dillon 1996 225-228.

${ }^{21}$ Apesar de esta concepçáo ser correctamente associada aos Estóicos, é curioso notar que também aparece em fragmentos de Epicuro (e.g. fr. 219 Usener = S. E. M. 11.169). Sobre esta questão, vide Teodorsson ad loc. 
inevitavelmente enquadrada pelas acçóes que cada um praticava; era, de facto, uma arte de viver. A este respeito, será esclarecedor o protesto que Cráton ${ }^{22}$ dirige contra aqueles que defendem que a filosofia deve ficar fora do banquete (613C):

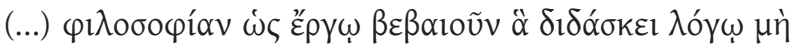
$\delta \cup v \alpha \mu \varepsilon ́ v \eta v$.

(...) como se [a filosofia] não tivesse a capacidade de confirmar por feitos aquilo que ensina por palavras.

Tendo em conta que esta frase se enquadra na discussão sobre a já analisada relação entre logos e vinho, não será abusivo assumir que ambas as questôes estão relacionadas. Neste caso, trata-se de associar o logos ao ergon, isto é, a componente teórica, racional e discursiva ao seu correlato factual e concretizado na esfera do real. Ao recorrer à noção de "confirmar", Cráton implica que haverá uma certa dependência do feito em relação ao dito/pensado; ou seja, aquilo que tem lugar na faculdade intelectiva e subsequente veiculação no intermediário linguístico determinará, de certo modo, a natureza do que acontece de facto. Entrecruzando as duas relaçóes, será o logos enquanto razão a disciplinar o consumo de vinho e, ao mesmo tempo, a determinar a natureza do ergon; por seu turno, o logos enquanto discurso racional é alimentado pelo consumo de vinho e essa harmonia será reflectida pelo e no ergon.

${ }^{22}$ Sobre esta personagem, vide supra 18-20. 
Deste triângulo conceptual resulta, a meu ver, uma necessária compatibilidade e interdependência entre os três elementos. Mais ainda, é nele que assenta a manutenção e o cultivo dos critérios éticos da amizade ( $\varphi \imath \lambda i ́ \alpha)$, filantropia $(\varphi \imath \lambda \alpha \vee \theta \rho \omega \pi i ́ \alpha)$, benevolência

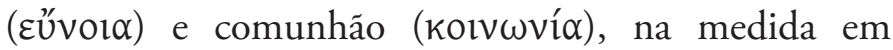
que a adequação dos comportamentos a estes axiomas depende de um consumo de vinho disciplinado pela racionalidade. É neste sentido que, para Plutarco (não só nas $Q C$ ), a filosofia consiste numa medicina da alma: o seu cultivo apaga a estupidez (ớvor $\alpha$ ), a intemperança

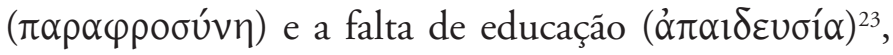
vícios que correspondem a uma contaminação do estado ideal do banquete.

Deste modo, todos os participantes, independentemente da sua condição, poderão tomar parte na discussão filosófica. Todavia, resta perceber como se processam exactamente esse tipo de investigaçóes.

Em primeiro lugar, convém esclarecer que as $Q C$ não são um tratado nem, por outro lado, se resumem a uma aproximação simplista aos problemas filosóficos que permita o seu entendimento rudimentar por todos os participantes. São sim, a meu ver, um guia prático sobre como aplicar categorias e pressupostos a situaçóes concretas ou facilmente representáveis; e, sobretudo, um paradigma de como conduzir uma discussão de modo racional.

A classificação de cada uma das secçôes dos nove livros como "problemas" ( $\pi \rho \circ \beta \lambda \eta ́ \mu \alpha \tau \alpha)$ não é inconsequente, pois filia a obra numa tradição que,

${ }^{23}$ Vide Becchi 199927. 
segundo se crê, remontará a Demócrito - embora esta ideia seja bastante discutível ${ }^{24}$. Em todo o caso, sugere conexôes com alguns tratados atribuídos a Aristóteles, hoje tidos por espúrios ${ }^{25}$, e até com o Livro III da Metafisica, que consiste em 14 problemas (em rigor, serão aporias) a que o autor tenta responder. É, de facto, este o espírito das discussóes travadas nas $Q C$; mais do que especular, o objectivo é responder a uma determinada questão, mais ou menos polémica, que é lançada aos participantes $^{26}$. Se quisermos, trata-se de resolver algo que, à primeira vista, causa espanto; uma aporia. Diz Plutarco que é a partir de um estado de perplexidade que nasce a filosofia (680C-D):

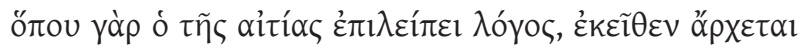

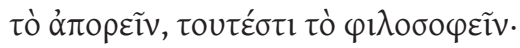

Onde falta a explicação da causa, aí começa o estado de perplexidade; isto é, a filosofia.

O motivo é já antigo. Por exemplo, Aristóteles diz logo no início da Metafísica (982b11-15) que os homens

${ }^{24}$ Tradicionalmente, diz-se que Demócrito terá redigido um tratado com o título Xepvıkò $\pi \rho \circ \beta \lambda \eta ́ \mu \alpha \tau \alpha$ (DK A 33.49 / B 299h = D.L. IX.49.11), mas a atribuição é duvidosa. Além do facto de não se ter conservado qualquer fragmento, mas apenas um título, a palavra Xepvıkó é um apax legomenon, razão pela qual se torna intraduzível.

${ }^{25}$ Trata-se dos Problemas [Físicos], citados recorrentemente nas $Q C$, e dos [Problemas] Mecânicos.

${ }^{26} \mathrm{O}$ sentido mais literal de $\pi \rho o ́ \beta \lambda \eta \mu \alpha$ é precisamente o de algo "lançado" ( $\beta \alpha ́ \lambda \lambda \omega)$ "perante" ou, mais literal ainda, "para a frente" ( $\pi \rho o ́)$. 
começam a filosofar quando se encontram num estado

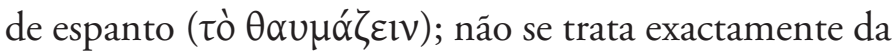
mesma formulação, mas o sentido é análogo.

Este género de debate requer, pois, um método próximo do dialéctico que permita resolver os problemas independentemente de o seu assunto ser ou não filosófico, dado que o objectivo fundamental é apurar a "causa" ( $\alpha i \tau i ́ \alpha)$ de um determinado problema por via de uma

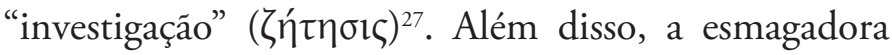
maioria dos títulos dos $\pi \rho \circ \beta \lambda \eta ́ n \alpha \tau \alpha$ começa justamente

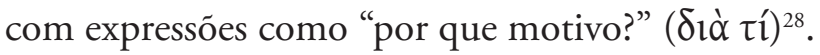

Isto não significa que todos os problemas levados ao debate sejam necessariamente resolvidos de modo conclusivo e definitivo; pelo contrário, o objectivo não é demonstrar o trânsito válido de premissas para conclusóes (como faria o discurso apodíctico), antes discutir dialecticamente através do exercício das faculdades racionais e argumentativas.

A dada altura, é lançada uma questão cuja veracidade seria bastante controversa: segundo algumas lendas populares, dizia-se que a tribo Eântide ${ }^{29}$ tinha o dom de nunca ser classificada em último lugar nas cerimónias festivas (628A sqq.). Dado o seu carácter duvidoso, os participantes discutem se valerá a pena sequer considerá-la. De imediato, Filopapo defende que o facto de uma proposição ser falsa ou verdadeira

${ }^{27}$ Apud Van der Stockt 200096.

28 Convém notar que há largas dezenas de ocorrências de

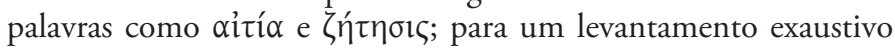
destes termos, vide Lopes 2009422 nn. 19-20.

${ }^{29}$ Uma das tribos da Ática. 
é irrelevante. Para reforçar a sua posição refere a atitude de Demócrito quando um dia comeu um pepino adocicado: tendo procurado saber a todo o custo a que se devia aquele admirável fenómeno, descobriu que a criada o tinha deixado, por acidente, numa vasilha com mel. Mesmo assim, Demócrito não desistiu de procurar a causa da doçura, pressupondo, mesmo assim, que estava relacionada com o local e as condiçóes em que o pepino tinha sido cultivado $(628 \mathrm{C}-\mathrm{D})^{30}$. Filopapo termina argumentando que, tal como Demócrito, eles próprios devem assumir que não deverá ser a conclusão de um problema a determinar a sua investigação; pois a discussão servirá pelo menos para praticar (628D).

Como muito bem observa Van der Stockt (2000 97-98), esta forma de encarar os problemas faz lembrar o espírito científico da Academia platónica, onde se privilegiava o caminho para atingir uma conclusão, em detrimento da conclusão em si. A este respeito, cumpre recordar o testemunho de Epícrates que, mesmo sendo algo anedótico, demonstra com clareza em que consistia este método. Segundo o comediógrafo (fr. $10 \mathrm{KA}=$ Ath. Epit. 2.59; Eust. 864.31), Platão tinha o costume de juntar os seus discípulos nos jardins da Academia, aos quais pedia definiçóes das plantas lá existentes. $\mathrm{O}$ caso mais problemático era o da abóbora, já que poderia pertencer a mais do que uma categoria: alguns diziam que era um vegetal esférico, outros defendiam que se tratava

${ }^{30}$ DK A 17a. Note-se que esta passagem de No Banquete é o único testemunho desta estória. Talvez por isso, e pelo seu carácter anedótico, os editores de Demócrito referem, no comentário ao fragmento, que se trata de uma paródia ao seu método etiológico. 
de um tipo de erva, e outros ainda associavam-na a um arbusto. Enquanto todos os aprendizes confrontavam as suas posiçóes, Platáo ia observando e moderando a discussão. Quer isto dizer que mais importante do que definir a abóbora era testar as várias formas de chegar a essa definição; não se tratava de um exercício de taxonomia, muito menos de botânica, mas sim de uma prova de dialéctica.

Ora, as $Q C$ serão um texto filosófico não só por abordarem alguns temas desta natureza, mas também e principalmente pelo facto de a sua estrutura mais íntima e profunda ser de matriz claramente filosófica.

\section{Conspecto geral dos temas filosóficos}

Pelo facto de os problemas a abordar deverem estar ao alcance de todos os participantes, a maior parte deles situa-se no âmbito da filosofia natural ou física - tal como estes conceitos eram entendidos pelos antigos - e em várias das suas ramificaçóes. No fundo, as atençốes estarão centradas maioritariamente em questôes concretas, cujos referente e contexto possam ser reconhecidos com facilidade.

A natureza do Homem é um dos tópicos mais recorrentes, nomeadamente alguns aspectos sobre psicologia $(3.6 ; 8.10)$ e fisiologia $(2.2 ; 4.10 ; 7.1 ; 8.8$; 9.10) em geral, e, em particular, as origens e causas das doenças $(6.8 ; 8.9)$ ou o modo como os humanos se relacionam com as sensaçôes e afecçóes $(1.8 ; 3.4 ; 5.1$; $6.1-3 ; 7.3,5 ; 8.3)$. Por outro lado, dado que o vinho desempenha um papel fundamental no banquete, 
há também várias discussóes sobre os seus efeitos e propriedades (1.6-7; 3.3, 7-9; 3.5).

Além do homem, abordam-se alguns aspectos relacionados com os outros animais $(2.3,7-9 ; 3.10$; $4.4 ; 6.10 ; 8.8)$, as plantas $(2.6 ; 3.2 ; 4.2 ; 5.9 ; 6.10)$, os elementos $(1.9 ; 6.4-6)$ e até a astronomia $(4.7 ; 9.9)$.

Quanto às fontes e pressupostos teóricos que presidem ao debate sobre estas matérias, é tentador apontar a tradição peripatética como base de dados principal, dadas as dezenas de citaçóes de obras dessa orientação, como por exemplo os Problemas [Físicos] na altura atribuídos a Aristóteles. Porém, essa associação tem algumas reservas, dado que poucas são as vezes em que o axioma aristotélico corresponde à conclusão final (e.g. 659D; 696D; 702B): na maioria dos casos, as citaçóes ou referências a esta tradição servem como mote inicial (650A; 652A; 656B-D; 690C,F; 704F; 720D; $734 \mathrm{E} ; 735 \mathrm{C})$ e, menos frequentemente, acabarão por ser inteiramente refutadas (627A-D; 694D; 724D). É que, acima de tudo, Plutarco é um platonista e, como tal, recorre a essa escola também para responder a questóes físicas - nestes aspectos será o Timeu a fonte preferencial. Contudo, isso não quer dizer que Plutarco siga apenas e só as doutrinas de Platão; convém ter presente que o Médio-Platonismo é marcado por uma forte influência de outras correntes de pensamento, como o pitagorismo ou o estoicismo ${ }^{31}$.

31 Sobre as tendências da filosofia natural ou física durante o Médio-Platonismo, vide Dillon 1996 45-49; este mesmo autor dedica uma secção exclusiva ao caso particular de Plutarco (199-225). 
De um modo geral, as discussóes sobre aspectos físicos parecem ser destinadas a refutar as crenças erróneas do senso-comum, substituindo-as por convicçóes assentes num conhecimento teórico validado pelas grandes escolas ${ }^{32}$. Alguns exemplos: a causa do abrandamento dos barcos não é a rémora, mas sim a deterioração da quilha (2.7); as trufas não são geradas pelos raios de trovoada que penetram o solo, mas sim pela natureza da água da chuva $(4.2)^{33}$.

\section{UM ESBOÇO DE COSMOLOGIA}

Um dos vários problemas filosóficos discutidos à mesa tem que ver com a formação e funcionamento interno do universo; isto é, a cosmologia. Não quero sequer sugerir que as $Q C$ sejam um tratado da tradição

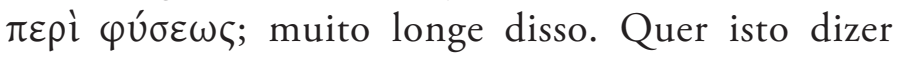
que não será possível encontrar no texto uma teoria (neste caso cosmológica) enquanto tal, isto é, um determinado conjunto de concepçóes estruturadas de modo rigoroso e sistemático. A alternativa será, pois, reunir um conjunto de elementos que se compatibilizem com as convicçôes e posiçôes teóricas globais de Plutarco.

32 O mesmo princípio se aplica a temas não filosóficos: o raciocínio e a prova do método dialéctico substituem a crença popular. Por exemplo, conclui-se que Mitridates era chamado Diónisos porque também ele fora atingido por um raio enquanto criança e não porque consumisse muito vinho (1.6).

${ }^{33}$ Para uma análise detalhada desta questão em particular, vide Setaioli 2009. 
Além deste problema, há ainda que equacionar o da voz autoral: entre tantas propostas adiantadas por tantos participantes, quais podemos identificar com as reais concepçóes de Plutarco? Decerto que considerar "autêntica" toda e qualquer proposição será não só perigoso, como também absurdo. Note-se, acima de tudo, que algumas ideias são referidas exclusivamente para serem refutadas. Regra geral, as concepçôes do "autor Plutarco" correspondem às teses defendidas pela "personagem Plutarco" ou por alguma outra que partilhe das suas convicçóes - geralmente um familiar próximo ou um amigo ${ }^{34}$.

Segundo Plutarco, o acaso ( $\tau u ́ x \eta)$ não participa na formação e funcionamento do mundo sensível; o que seria absolutamente expectável, dada a sua absoluta aversão a axiomas filosóficos atomistas - tanto na versão mais antiga, de Leucipo e Demócrito, como, e principalmente, na que sustenta o epicurismo. Isto não significa que o Queronense rejeite a acção da

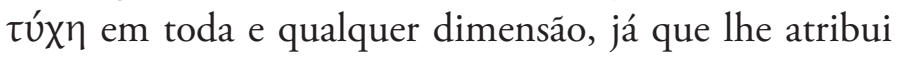
um valor considerável em determinadas condiçóes, nomeadamente quando discute questóes históricas; mas quando o contexto sugere algum tipo de ligação com o epicurismo, segue-se inevitavelmente a sua refutação ${ }^{35}$. Quando, durante uma discussão sobre o uso de flores

34 Sobre a questão autoral, vide Martín García 1987 12-14; Ferrari 1995 30-31.

35 A observação é de Brenk 1977 154. Em sentido análogo,

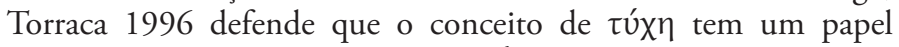

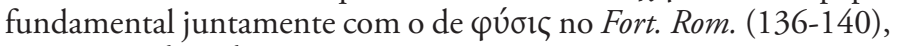

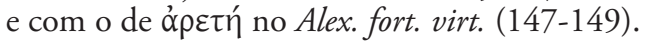


no banquete, se defende que o único propósito natural destes seres vegetais é gerar um prazer olfactivo e visual, não está em causa a tese epicurista segundo a qual o

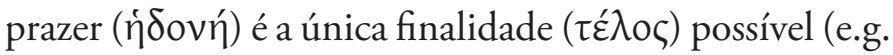
D.L. 10.128-129), antes o axioma segundo o qual todas as coisas foram criadas com uma finalidade específica (646C):

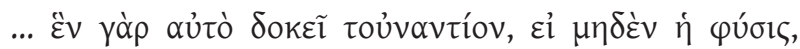

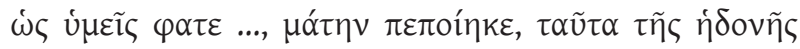

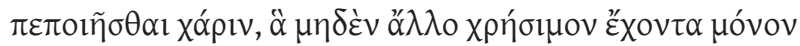

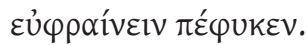

$\mathrm{Eu}$, pelo contrário, creio que se a natureza náo criou nada em vão, como vocês dizem, foi em funçáo do prazer que criou aquilo que por natureza apenas serve para deleitar e não tem qualquer outra utilidade.

O facto de o prazer ser uma finalidadeé uma simples coincidência, posto que a ideia central é a inexistência de acaso na natureza: todas as coisas funcionam do modo como é suposto que funcionem; mesmo as coisas mais simples como as flores têm um determinado papel a desempenhar. Numa outra discussão, a propósito da propagação dos sons durante a noite, Amónio (o mestre de Plutarco) ${ }^{36}$ defende que a Providência (720D: $\pi \rho o ́ v o l \alpha)$ conferiu acuidade à audição para compensar as limitaçóes da visão (720E).

Ambas as passagens sugerem uma concepção orientada do universo segundo a qual os processos

${ }^{36}$ Sobre esta personagem, vide supra 26-29. 
naturais foram determinados previamente à sua criação - algo diametralmente oposto à teoria atomista da casualidade. Mas o ponto mais interessante que esta ideia evidencia tem que ver com o sincretismo filosófico que define o pensamento de Plutarco e do Médio-Platonismo em geral; é que são possíveis três tradiçóes diferentes para a explicar. $\mathrm{Na}$ frase inicial da primeira passagem cita, quase ipsis uerbis, uma secção do De Anima (434a31-32) de Aristóteles:

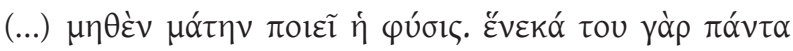

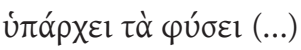

(...) a natureza não cria nada em vão, pois tudo é, por natureza, em funçáo de alguma coisa (...). ${ }^{37}$

Ora, a tentação seria dizer que Plutarco segue a concepção aristotélica da teleologia natural, segundo a qual todas as coisas estão delimitadas pela sua causa final. Porém, a referência à đeóvoı $\alpha$ introduz mais duas variáveis na equação. Em primeiro lugar, a concepção estóica de Providência, que nesta altura não era somente a pura inevitabilidade e necessidade, porque havia já absorvido a racionalidade da teleologia aristotélica ${ }^{38}$. Em seguida, a própria concepção platónica de criação como acto racional e teleológico, que Plutarco convoca para explicar um problema de anatomia: os animais têm o número exacto de órgáos para sobreviver, sendo que

${ }^{37}$ A mesma ideia é repetida em Cael. 290a31, GA 744a36-37, Ph. 197b22-29.

${ }^{38}$ E.g. SVF 2.945 / LS 55N = Alex. Aphr. Fat.191.30-192.28. 
a cada um deles está associada uma função fisiológica específica (699E-F).

Este é um problema deveras delicado, cujo esclarecimento exigiria uma reflexão bem mais aprofundada e exaustiva ${ }^{39}$. Tenhamos apenas em mente que, apesar do referido sincretismo filosófico, Plutarco não deixa de ser um platonista; por isso, os contributos de outras correntes de pensamento serão elementos complementares a uma matriz mais profundamente enraizada.

É neste sentido que surge a segunda questão do Livro VIII, uma das secçóes mais importantes no que diz respeito à cosmologia ${ }^{40}$. O título por si só é sugestivo: "Em que sentido dizia Platão que o deus estava sempre a fazer geometria?” As conexôes que cumpre estabelecer são duas: uma, mais evidente, com o Timeu de Platão, onde aparece a figura do demiurgo que fabrica o universo justamente pelo recurso à geometria; outra, em relação a um texto de Plutarco, com a segunda das Platonicae quaestiones, onde se defende que o deus é o pai dos homens e o criador do universo, o que representa uma visão algo distante do texto de Platão, segundo o qual o demiurgo se retira após a criação ${ }^{41}$. Dadas as complexidades

39 Para uma breve síntese do problema da Providência em Plutarco, vide Dillon 1996 208-211; sobre as relaçóes com o conceito estóico, vide Babut 1969 453-465, Hershbell 1992 3348; quanto às ligaçóes com a física aristotélica em geral, vide Donini 1992.

${ }^{40}$ Esta questão foi minuciosamente interpretada em Ferrari 2009.

${ }^{41}$ Nos parágrafos que antecedem esta questão, aparece uma

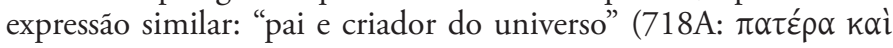


inerentes a esta questão, cujo esclarecimento requereria uma análise mais aprofundada, vejamos apenas como o próprio Plutarco conclui (720B-C):

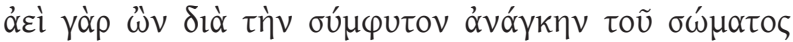

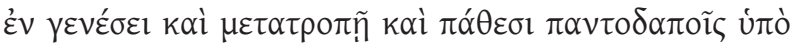

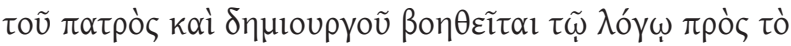

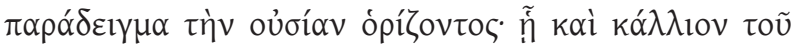

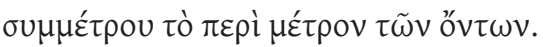

Em virtude de estar continuamente envolvido no devir, na mudança e em todo o tipo de afecçóes, por uma necessidade conatural ao corpo, [o universo] é auxiliado pelo pai e criador que, por meio da razáo, delimita a essência de acordo como o arquétipo; por isso, o que diz respeito à medida das coisas é mais belo do que a simetria.

A meu ver, há dois pontos essenciais a considerar: a referência à geometria e o uso da palavra "sempre" (ảcí). Quanto ao primeiro, a sua explicação é bastante simples: o deus (ou Deus, se quisermos) fabricou o mundo através daquilo a que nós, humanos, concebemos como geometria: uma ordem de inteligibilidade imposta pelos limites matemáticos à matéria desordenada ${ }^{42}$. Já o segundo é bastante mais complexo em relação a um aspecto. Se, por um lado, é claro que a Providência em

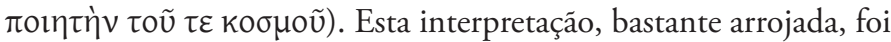
rejeitada e condenada logo por Proclo (in Tim. 1.319.15-16). Para uma análise exaustiva desta secção das Platonicae quaestiones, vide Ferrari 1996.

${ }^{42}$ A matematização do universo era um motivo filosófico bastante caro a Plutarco; sobre o assunto, vide Ferrari 1995 117-147. 
si consiste na manutenção da observância ao arquétipo, isto é, da orientação racional de todo o reino do devir em relaçáo às Formas, o modo como o deus exerce essa Providência é uma questão que permanece ainda em aberto.

Resta apenas sistematizar algumas consideraçóes finais.

O banquete segundo Plutarco inscreve-se, sem dúvida, na tradição filosófica iniciada por Platão; não só pelo facto de o próprio autor assumir directamente esse propósito, mas também pelo código ético rigoroso que preside a discussão e por a filosofia (principalmente a chamada física) ser assunto de debate. Por outro lado, as $Q C$ deixam transparecer uma versão personalizada da filosofia que esteja ao alcance de todos os convivas, os quais, pelo poder libertador e criativo do vinho regulado pela racionalidade, podem participar nas discussões em igualdade de circunstâncias. Não obstante, há ainda espaço para algumas discussóes de alcance filosófico considerável, como por exemplo este esboço de cosmologia. 